\title{
XOKLÉNG E KAINGÁNG
}

\section{(Notas para um estudo comparativo)}

\section{Francisco S. G. Schaden}

Não há dúvida de que o idioma falado pelos índios Xokléng de Santa Catarina é dialeto da língua Kaingáng, que é peculiar a grupos indígenas dos quatro estados sulinos e de territórios contíguos da República Argentina. Essa classificação da língua daqueles aborígenes catarinenses - aceita por muitos autores, como José Maria de Paula, Simoens da Silva, Chestmír Loukotka, Jules Henry e outros - foi corroborada há vários anos por um valioso estudo de Rosário Farani Mansur Guérios, professor da Faculdade de Filosofia de Curitiba e um dos mais competentes lingüístas do país. Opiniões como a de A. Fric, segundo a qual - idioma Xokléng deveria ser considerado antigo dialeto Guaraní, são inteiramente insustentáveis por lhes faltar tôda base científica.

Também do ponto de vista somático não parece haver diferenças notáveis entre índios Kaingáng e Xokléng. E' pelo menos o que se depreende das observações dos cientistas que os visitaram. Todavia, não possuímos dados antropométricos que possam servir de base para um estudo comparativo. As medições feitas por Egon Schaden em índios Kaingáng do oeste paranaense ainda não foram elaborados cientificamente, e também quanto aos Xokléng parece que não se publicaram até hoje quaisquer tabelas antropométricas. - Em todo caso, porém, não se pode concordar com a afirmação de A. Fric, que caracteriza os Xokléng como indígenas de estatura anã.

No tocante aos diferentes setores da cultura, às formas de comportamento e à vida psíquica em geral, talvez seja possível tentar um rápido esbôço comparativo. E' o que se pretende fazer nestas páginas, que, entretanto, não passam de notas preliminares, porquanto se baseiam sòmente em pequena parcela das fontes disponíveis. Desejamos encarar a questão primordialmente do ponto de vista dos contactos com o mundo civilizado. Quanto aos Kaingáng, conhecidos também como Coroados, limitâmo-nos, na medida do possível, aos de Palmas, sôbre os quais possuímos material mais consistente, colhido sobretudo por Baldus.

Numa caracterização geral, - que, evidentemente, sofre do mal de tôdas as generalizações nessa ordem de problemas, - talvez se possa dizer, de início, que em face do homem branco os índios Kaingáng revelaram maior astúcia, gênio mais vingativo e menor sinceridade do que os Xokléng. 
Essa afirmação se baseia nos seguintes fatos. Muito tempo antes de se pacificarem os Xokléng, conseguiu-se fundar o aldeamento dos Kaingáng de Palmas. Apesar disso, continuavam em tôda aquela região os assaltos dos índios a sítios habitados por gente civilizada. Em geral, acusavam-se os Xokléng da autoria dêsses atos, o que, entretanto, era injusto e não correspondia à realidade, como se depreende do testemunho de Frei Solano Schmidt, missionário franciscano que por longo tempo exerceu o seu ministério nos sertões do oeste de Santa Catarina e do Paraná.

Escreve o missionário: "No que respeita à "mansidão" dos Coroados de Palmas, diga-se que ela não é lá grande coisa. A êles precisamente se atribui a maioria dos assaltos que ocorrem no campo de Santa Catarina e na estrada de Curitiba a Blumenau. E, como eu mesmo pude verificar, é fato verídico que os moradores dos toldos de Xapecó, Formigas e Xapecòzinho desaparecem anualmente por alguns meses, sem que pessoa alguma descubra o rumo que tomaram. E daí em breve ouve-se então falar de assaltos de bugres, de assassínios e pilhagens, até que uma certa manhã a fumaça que se levanta dos ranchos indica aos vizinhos que os índios voltaram, da noite para o dia, de sua longa e misteriosa excursão. Não denunciam nunca os verdadeiros objetivos de suas viagens; sòmerite depois de um intervalo de vários meses é que oferecem à venda uma série de objetos manifestamente roubados" ${ }^{1}$.

O mesmo autor narra o seguinte episódio: "Contaram-me uma história que se passou há uma série de anos e que atesta as correrias dos Coroados. Um fazendeiro de Guarapuava, chamado Pedro Lustosa, dirigia-se, com uma grande tropa, do campo de Santa Catarina ao litoral. Durante a viagem foi assaltado por bugres. O guia, que andava na dianteira, foi morto a flechadas juntamente com o seu animal, e assim imobilizou-se na estreita picada a longa fila da tropa. Sôbre Pedro Lustosa e seus companheiros derramou-se uma chuva de flechas, e em seguida os índios saíram do mato com as suas clavas e, apesar de desesperada resistência, as homens, um depois do outro, foram caindo de seus cavalos, vitimados pelas flechas. Pedro Lustosa, que for fim ficara como único sobrevivente, confiava em seu vigoroso cavalo e deu-lhe as esporas, conseguindo, assim, romper as fileiras de seus inimigos. Passou com o animal por cima de um índio que se the opunha no caminho, e a outro, que tencionava pegar as rédeas do cavalo, derrubou com uma coronhada. Conseguiu fugir, embora perdendo a tropa. Durante algum tempo Pedro Lustosa permaneceu no campo de Santa Catarina, para depois voltar a Guarapuava, passando por Palmas. Qual não foi o seu assombro quando em Palmas deu com o índio a que derrubara com a corcnha, sem, no entanto, lhe esfacelar o duro crâneo. Mas o seu espanto ficou ainda maior quando o índio o enfrentou no meio da rua e, 
apontando para a cicatriz que levava na testa, the disse: "Senhor Pedro, esta marca the vai custar caro". Quando daí a muitos anos, no tempo em que passei em Palmas, morreu Pedro Lustosa, o índio, que eu mesmo conheci muito bem, ficou francamente furioso, dizendo a um conhecido: "Agora morreu Pedro Lustosa, sem que eu pudesse matá-1o. Quantas vêzes não fiquei à espreita dêle, mas sempre acontecia algum imprevisto, de sorte que me escapava, e agora êle está morto e eu não me pude vingar."'"2

Frei Solano cita outros casos do gênero. Mas êsses fatos isolados evidentemente não se prestam para caracterizar a indole de um grupo ou duma tribo inteira. De outro lado, é verdade que os Kaingáng dos campos de Palmas, e também de outras regiões do Brasil Meridional, por muito tempo não lograram desfrutar a confiança dos fazendeiros e outros moradores. Naturalmente não se pode acreditar em tôdas as acusações que thes eram feitas pela imprensa e pela voz do povo em geral, e muites crueldades praticadas por êsses índios não passavam, é claro, de reação muito natural à maneira pouco decente e pouco humana com que eram tratados. Assim mesmo, parece fora de dúvida que os Kaingáng se distinguiam por um caráter impulsivo e violento.

Antes de nos referirmos a um ou outro traço geral da indole dos Xokléng, parece oportuno dar algumas informaz̃ões sumárias sôbre a distribuição geográfica dêste grupo.

$\mathrm{Na}$ época do descobrimento, o litoral catarinense era ocupado, em tôda ou quase tôda a sua extensão, pelos índios Karijó, do Grupo GuaIaní. Em muitos pontos da faixa litorânea dêsse Estado, desenterraram-se, aliás, igaçabas ou urnas funerárias que parecem datar do tempo dos Karijó. O Pe. Schulz, vigário de São Ludgero (Braço do Norte), explorou vários cemitérios de índios, recolhendo algumas das urnas encontradas ao museu do colégio paroquial. O fato de se descobrirem sempre várias urnas no mesmo sítio atesta que os índios em aprêço levavam uma vida relativamente sedentária.

Na Serra do Mar, porém, e nas terras que se estendem para o oeste - e para o norte, pelo território paranaense a dentro - dominavam os Xokléng e grupos afins, conhecidos em seu conjunto sob a denominação de Botocudos de Santa Catarina. Pelo menos foram encontrados como senhores da região, quando, há cento e tantos anos, se iniciou a coloniLação estrangeira no interior catarinense. Hoje em dia já não se consegue determinar, com relativa exatidão, a linha divisória entre o habitat dessa tribo e o dos Guaraní. E' possível que a localização de igaçabas ainda venha a elucidar em parte o probleme. Afirma-se que foram descobertas urnas de barro também nos arredores de Tubarão. O próprio nome da cidade e do município deriva do apelido de um grande chefe Karijó. Mais para o norte, todavia, a faixa de ocupação Guaraní era 
muito mais estreita. Nessa parte (ao que nos consta) os sítios em que se encontraram igaçabas ficam todos a pequena distância do mar. E' notório que os Botocudos não usavam urnas funerárias.

Sôbre as hordas meridionais dêstes últimos, que avançavam pelas terras do Rio Grande a dentro, estamos muito mal informados. Um dos poucos autores que a elas se referem é Reinhold Hensel ${ }^{3}$, que escreve o seguinte: "No Norte da Província (do Rio Grande), i. é, na chamada serra ou no planalto e nas extensas florestas do terraço que medeia entre êste e a planície, havia Botocudos, que se distinguiam dos Botocudos mais setentrionais por terem no lábio inferior apenas um pequeno orifício sem botoque de madeira e que utilizavam para assobiar. Eram muito temidos por causa de sua braveza e ainda importunavam com freqüência os primeiros colonos alemães na mata virgem. Hoje parecem estar inteiramente repelidos, limitando-se às Províncias do $\mathrm{Pa}$ raná e de Santa Catarina, onde sobretudo a colônia de Brusque continua exposta a suas rapinagens".

E logo adiante, passando a tratar dos Kaingáng, que na época já constituíam o contingente indígena; mais importante do território gaúcho: "No Rio Grande do Sul parecem ter vindo estabelecer-se apenas em época relativamente recente, porquanto nas regiões por êles habitadas atualmente, não se encontram quaisquer nomes de localidades tomados ao seu idioma. Parecem ter vindo dos lados do noroeste, talvez da Província do Paraná e, em luta com os já mencionados Botocudos, foram impelindo a êstes para a frente, fazendo-os entrar finalmente na Província de Santa Catarina, em parte por certo com o apoio do govêrno brasileiro, que os utilizava como instrumento no combate àqueles perigosos saqueadores".

Os Xokléng eram índios da mata, que se dirigiam para os faxinais vizinhos sòmente no inverno, quando estavam maduros os pinhões. De modo geral, a zona dos campos, até as margens ou proximidades do Rio Paraná, constituía o domínio dos índios Kaingáng. Êstes, que parecem ter sido muito mais numerosos do que os Xokléng, estendiam-se, na direção do norte, por quase todo o oeste paulista.

A pacificação dos Xokléng foi conseguida no ano de 1914, graças ao enérgico e corajoso Eduardo da. Lima e Silva Hoerhan, organizador do Pôsto Duque de Caxias, no Rio Plate. Até aí, a tribo havia sido considerada por quase todos como essencialmente "refratária à civilização", de modo que se chegou a propor a sua extinção total pela violência. Constituíam a última população indígena do Brasil meridional que resistia a quaisquer tentativas de pacificação. O território da horda, formado talvez de uns 500 indivíduos, já não era muito grande e ia diminuindo progressivamente pelo avanço da colonização estrangeira. Não se deve admirar, pois, a ocorrência de contactos hostis entre índios e 
colonos nas zonas fronteiriças dos dois domínios. Baseando-se nas indicações dos moradores mais antigos de Blumenau, o Dr. Hugo Grensch calculava, no ano de 1908, em inferior a trinta o número de brancos mortos nesses encontros desde a fundação da colônia de Blumenau. Mais tarde, José Deeke, consultando tôda a documentação acessível e os noticiários da imprensa, fêz uma tabela dos assaltos de índios havidos entre 1852 e 1914. Assinala um total de 61 assaltos, em que morreram 41 brancos, ficando feridos outros 22. Embora não haja indicação expressa neste sentido, parece tratar-se, na grande maioria dos casos, de incursões atribuídas aos Xokléng.

Numa região como a de Blumenau, onde havia imigrantes hábeis no manejo da pena e onde existia uma imprensa local, naturalmente se registravam e divulgavam tôdas as ocorrências dessa ordem. Mas na zona ocidental do Estado, habitada por uma população muito esparsa, constituída sobretudo de capatazes e peões, naturalmente se propalavam também as notícias de encontros hostis com índios, mas, como ninguém cuidasse de assentar por escrito essas ocorrências, não possuímos hoie em dia dados precisos para um confronto com o material relativo aos Xokléng. Tudo leva a crer, porém, que os choques havidos com os Kaingáng do Paraná e de Santa Catarina, no período que precedeu à pacificação dêstes grupos, não tenham sido menos numerosos do que as incursões praticadas pelos Xokléng ou a êles atribuídas.

Não parece haver dúvida de que a razão principal dos encontros hostis com os Xokléng residia na redução de seu primitivo domínio. Sem mais nem menos, o govêrno ia concedendo terras às emprêsas colonizadoras e, embora se considerasse protetor dos silvícolas, não se preocupava absolutamente com os interêsses dêstes. Um golpe doloroso para a tribo dos Xokléng foi também a fundação das colônias federais de Anitápolis e Esteves Júnior, em 1907 e 1908, que thes reduziu ainda mais o território de caça. Sòmente em 1926, portanto muito depois da pacificação, o govêrno catarinense, então chefiado por Adolfo Konder, concedeu aos Xokléng um patrimônio de quinze mil hectares de mata virgem.

Com freqüência, os imigrantes se armavam de espingarda, entregando-se à caça nas florestas próximas às colônias. Acontecia, nessas ocasiões, que matavam prêsas levantadas pelos índios, levando-as consigo sem dar satisfação aos silvícolas. Cada vez mais prejudicados em seus recursos de subsistência, os Xokléng trataram de amedrontar os brancos por meio de incursões, na expectativa talvez de impedirem o avanço da colonização. A medida foi, porém, contraproducente, pois os colonos passaram, por sua vez, a organizar grupos armados para afugentar os aborígenes. Em virtude da superioridade das armas e da astúcia diabólica empregada pelos chamados bugreiros, individuos sem escrúpulos 
que chefiavam essas expedições, registrou-se um número relativamente grande de vítimas entre os primitivos donos daquelas matas. Muitas mulheres e crianças indígenas perderam a vida em episódios vergonhosos e de repugnante crueldade que se passaram nos acampamentos da floresta. Evidentemente, não era por êsses meios que se havia de despertar nos aborígenes o desêjo de se aproximarem da civilização.

Nas incursões que praticaram contra casas de colonos, os Xokléng se manifestaram muito menos cruéis e bárbaros do que se costuma afirmar. José Deeke refere um único caso em que mutilaram o cadáver de uma de suas vítimas. Uma das incursões é por êle relatada da seguinte maneira: "Pouco mais tarde, em outubro de 1906, irromperam no sítio de Paul Krause, no Rio dos Índios, onde mataram uma menina de treze anos e roubaram muita roupa e utensílios. - Neste último assalto podia-se, aliás, verificar mais uma vez que os silvícolas não vinham diretamente com a intenção de matar. O ódio aos brancos e a vingança sangüinolenta que lhes teriam jurado não passava e não pessa de ficção. O silvícola não quer outra coisa senão obter os artigas de que precisa, utensílios de ferro, tecidos etc. Sem dúvida, não sente a menor inibição, quando se trata de despachar um branco para o outro mundo, mas não era essa a finalidade dos essaltos. No sítio de Krause, por exemplo, mataram a menina sòmente porque ela saira correndo em direção da roça para avisar os pais, coiss: que naturalmente queriam impedir. Uma criança de pouca idade, que se encontrava no berço, não foi por êles molestada; tencionavam apenas apoderar-se das fronhas (Nota: $\mathrm{Na}$ borda da mata, os silvícolas tiraram as plumas dias almofedas, levando sòmente os panos de fôrro e as fronhas.), e para isso tiraram a criança, colocando-a no chão" "

Das crianças Xokléng trazidas do interior da mata a maior parte faleceu depois de curto prazo. As que lograram vencer as saudades da floresta e acostumar-se ao novo regime alimentar, integraram-se de maneira satisfatória na vida civilizada. Eram crianças cuja idade, na ocasião de seiem retiradas da mata virgem, variava entre seis e doze anos, aproximadamente. Possuímos informes interessantes, embora escassos, sôbre algumas delas; as mais conhecidas são os filhos adotivos dos Dres. Weigand e Gensch e do Padre Topp, bem como um índio de nome Gregório, educado pelos Frades Franciscanos de Blumenau, e outro, Dilly Nuklé, que freqüentou o Ginásio Catarinense, de Florianópolis.

A pacificação da tribo dos Xokléng data de Setembro de 1914. Entre os órgãos da imprensa de Blumenau destacavam-se até então o jornal "Der Urwaldsbote" em sua atitude hostil aos silvícolas, noticiando com grande indignação e de maneira espalhafatosa as incursões realizadas na colônia. Estabelecido, porém, o contacto entre o Serviço de Pruteção coos Indios e a "indomável" tribo, felizmente não se deu mais nenhum ca- 
so dessa ordem que pudesse ser explorado pela imprensa. E' ve idade $^{-}$ que a tarefa dos funcionários do Pôsto Duque de Caxias, aldeanıento fundado para os Xokléng, continuou sendo bastante penosa por vários anos, mas com o tempo os índios adotaram um regime de vida de trabalho e produção.

O Dr. Simoens da Silva, que fêz uma visita, ao pôsto há uns trinta anos, escreve: "Êsses índios, até então, alimentavam-se, exclusivamınte, de caça, de pesca", e de frutas: começando, depois do funcionamento cêsse centro de amparo aos mesmos, a plantarem para colher e a prestarem reais serviços ao lugar, então, escolhido para tal fim. Independente da abertura de picadão e estradas, que põem em comunicaçãu as diversas localidades do Pôsto, tratam do gado vacum e ovino e dos galináceos e palmípedes, com que, em dias determinados da semaná, se alimentam, bem assim, cultivam, já, em não pequena escala: mandioca e o aipim, batata inglêsa e doce, cana de açúcar, milho, feijão, erroz, amendoim, abóbora, inhame, taioba e alguns legumes. Também continuam a alimentar-se muito com pinhões, bananas, laranjas e tangerinas"'.

Entre os Kaingáng e os Xokléng não havia relações pacíficas. Em vista das constantes lutas entre as diferentes hordas da tribo dos Kaingáng, êsse fato poderia ser explicado simplesmente como rivalidade entre duas hordas Kaingáng. Todavia, deve-se notar que, segundo testemunho de vários autores, os próprios Kaingáng não reconhecem os Xokléng como grupo pertencente a sua tribo.

Os Kaingáng disseram a Baldus que costumam lutar de dia, enquanto as excursões guerreiras do Xokléng se realizariam na escuridão da noite. Nas fontes consultadas, não encontrei, porém, informações sôbre êste ponto. Em todo caso, é certo que os assaltos dos Xokléng contra as moradas de colonos se deram de dia. Tenho notícia de um único ataque noturno, efetuado contra uma turma de trabalhadores de estrada de ferro (e relatado por Erich Bendrath); mas, a julgar pela região sm que se verificou a ocorrência, é muito mais provável que seus autores tenham sido Kaingáng.

Diferença importante entre os dois grupos é o botoque labial, usado sòmente pelos homens da tribo dos Xokléng e não pelos Kaingáng. A ésse aderêço devem aquêles a denominação de Botocudos, enquanto os Kaingáng se tornaram conhecidos como Coroados por cortarein o cabelo em forma de tcnsura, costume em que, aliás, não se distinguem dos Xokléng.

A festa de iniciação tribal, em que o jovem é admitido ná categoria dos adultos, recebendo o seu primeiro botoque, é o acontecimento mais importante na vida social dos Xokléng. Entre os Kaings̉ng não se realizam ritos de iniciação e não é provável, tampouco, que essas 
cerimônias e o uso do botoque tenham existido entre êles em épocas antigas.

Outro ponto importante em que diferem as duas culturas é a atitude em face dos mortos. Herbert Baldus teve oportunidade de estudar o culto dos mortos no pôsto indígena Kaingáng de Palmas. Entre èsses índios, o entêrro do defunto é acompanhado de uma série de cerimônias e práticas tradicionais. As rezas que se cantam ou recitam nessa oportunidade contêm numerosos elementos arcaicos, que as tornam incompreensíveis às gerações atuais. Por sua vez, os Xokléng queimavam, numa fogueira especialmente preparada, o defunto e todos os objetos que the houvessem pertencido. A seguir, enterravam as partes não consumidas pelo fogo. Os corpos das crianças, porém, não er mados nem enterrados.

Essas diferenças no tratamento dos defuntos refletem por certo concepções diversas da morte e do Além. Infelizmente o material disponível não é suficiente para a discussão do problema. O mesmo cumpre dizer em relação a outros aspectos da vida religiosa e à mitologia.

Quando entraram em contacto com o mundo civilizado, os Kaingáng - em oposição aos Xokléng - já se dedicavam à lavoura, cultivando o milho e outros vegetais úteis. Habitando de preferência zonas abertas, revestidas de campos, tinham naturalmente maior facilidade no amanho da terra do que os Xokléng, que viviam no interior das matas, onde se alimentavam de caça e frutos silvestres. Por sua vez, não se dedicavam à pesca, que entre os Kaingáng constituía fonte de alimentos. Mas como na língua dêstes se empregam os têrmos guaraní pirá e narí para designar c peixe e o pari, é possível, se não provável, que a tribo tenha aprendido a pesca com os seus vizinhos.

Bastam estas rápidas observações para se ter idéia, embora sumária, do problema da situação cultural dos Xokléng em face dos Kaingáng. E' assunto muito complexo, que sòmente poderá ser discutido de modo satisfatório à luz de cuidadosas pesquisas etnológicas que venham a realizar-se no seio dos atuais remanescentes de ambas as tribos.

$$
\begin{aligned}
& * * * \\
& \text { NOTAS }
\end{aligned}
$$

(1) P. Solano Schmidt, O.F.M., "Unsere "zahmen" Indianer", Der Familienfreund, Pôrto Alegre, 1913, pgs. 40 43.

(2) Ibidem.

(3) "Die Coroados der brasilianischen Provinz Rio Grande do Sul", Zeitschrift für Ethnologie, vol. 1. ${ }^{\circ}$, pgs. 124-135; Berlim, 1869 .

(4) José Deeke, Das Munizip Blumenau und seine Entwicklungsgeschichte, vol. 3, pgs. 71-72. São Leopoldo, 1917.

(5) Neste ponto deve haver engano da parte do autor.

(6) Simoens da Silva, A Tribo Caingáng (fndios Bugres - Botocudos), pg.26. Rio de Janeiro, 1930 . 